\title{
Simple, Portable, and Inexpensive Spectrophotometers for High Schools Lab Activity
}

\author{
Ari Syahidul Shidiq*, Anna Permanasari, Hernani Hernani \\ Science Education Department, Postgraduate School \\ Universitas Pendidikan Indonesia \\ Bandung, Indonesia \\ *arishidiq@upi.edu, anna.permanasari@upi.edu, hernani@upi.edu
}

\begin{abstract}
A simple, portable and inexpensive spectrophotometer for chemical analysis and laboratory activities is a growing topic of research in chemical education. The purpose of this study was to investigate how academics develop simple, portable and inexpensive spectrophotometers in the chemistry classes. This study used a systematic literature review method. A total of 46 related journal articles from 2009 to 2019 were used as sources for review. Sources of the articles reviewed were mostly obtained from the Journal of Chemical Education. As a guide to the study conducted, three formulations of the problem were used. First, what type of instruments developed. Second, what specific technology used and third, what pedagogical approach used. The results of the study conducted indicate that the UV-Vis instrument is the most developed one. This opens up opportunities for other researchers to develop other types of spectrometry instruments. The use of LED technology as a light source and a smartphone camera as a detector is a currently developing innovation. The development and the use of simple spectrophotometer have been successfully conducted at various levels of education including high school. This proves that simple, portable and inexpensive spectrophotometers can be used and developed at the high school level.
\end{abstract}

Keywords: spectrophotometers, high school lab activities, systematic literature review

\section{INTRODUCTION}

Spectrophotometers are usually used in university laboratories and are rarely owned by high school laboratories [1]. Meanwhile, the introduction of spectrometry instrumentation in high schools can serve as a catalyst to attract students' interest in chemistry [2]. Chemistry lessons in the second year in high school are suitable for the introduction of instrumentation material [3]. The students in chemistry lessons are usually not interested in the topic of the lesson because it is not related to their daily lives [4]. By teaching them to use modern chemical instrumentation and its function to help deal with environmental problems such as water pollution, it is expected to increase their interest in chemistry [5].

General spectrophotometers are sold at a cost ranging from 3,000 to more than 20,000 USD; this becomes a problem for schools and universities in developing countries like Indonesia. For this reason, a number of studies on producing simple, portable, and inexpensive spectrophotometers for laboratory activities and chemical analysis have become one of the topics of research aimed at chemistry researchers to answer current problems [6,7].

Spectrophotometer instruments are used to measure the degree of absorbance of light at certain wavelengths. Light sources, monochromators, and detectors are the main parts of spectrophotometer instruments. The light source serves to determine the wavelength. The detector functions as a tool to quantify the intensity of light that is not absorbed by the substances in the sample. Monochromator function to separate the light produced by the light source to be smaller [1].

Modification of spectrophotometer instruments can be done by innovating on the main part of the spectrophotometer, such as using a pointer light as a light source [8] and LEDs [2,9,10], and using Arduino and digital cameras as a detector [7,11-13]. In addition, various types of spectrophotometer instruments have been developed such as UV-Vis [14-17], Flame photometer $[18,19]$ and spectrophotometer simulations using computer programs and augmented reality [20,21]

There are a lot of literatures that discuss the development of spectrophotometers showing that research on this issue is at least being carried out. However, accurate assessment and documentation of what has been done, how to do it and what can be done by researchers in the future to develop a spectrophotometer must be informed thoroughly and comprehensively. Through a systematic review of existing literature, this study aims to investigate how academics innovate to develop spectrophotometers in chemistry classes. In addition, further studies on technological and pedagogical aspects need to be explored.

\section{METHODS}

A Systematic literature review method was used in this study to critically assess how academics innovate to develop spectrophotometers in chemistry classes [22]. A systematic review of the literature applies explicit methodological processes to produce a synthesis of evidences. In this study we recognize the influence of our own subjectivity in interpretations, as well as the limitations from information provided by the authors of original papers. In order for a 
at the level of high school and college using innovative approaches and technologies are presented in the Table 1:

formulation is used as a guide for literature review. The formulations of the problems in this study are: What instruments are developed? What specific technology is used?; and What pedagogical approach is used?. The systematic literature review scheme can be seen in Figure 1.

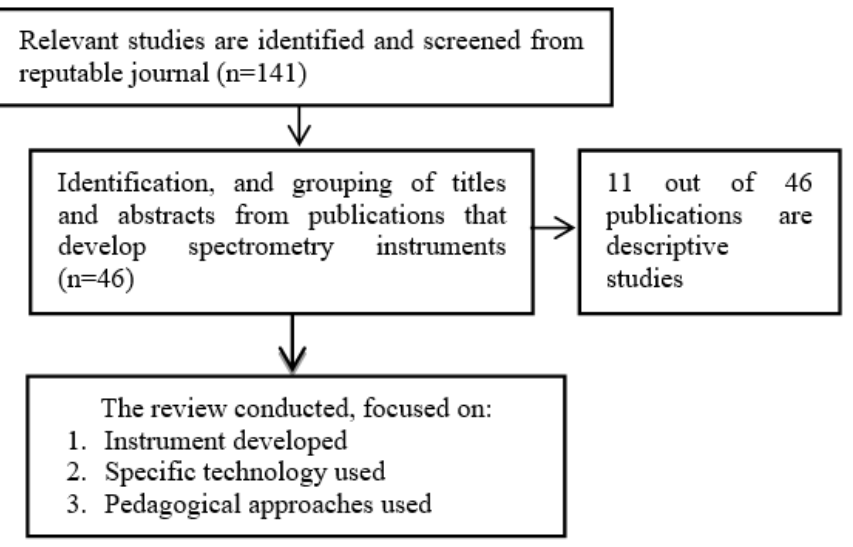

Fig. 1. The systematic literature review scheme.

The review carried out in this study focuses on the publication of spectrophotometers development in a reputable journal. Sources of the articles reviewed were mostly obtained from the Journal of Chemical Education. We recognize that publications on the development of spectrophotometers can appear in various other reputable journals. However, our choices are based on the large number of publications on the development of spectrophotometers in the reputable journal, the results of preliminary studies and careful review of article titles.

Searching for publications using the keywords produces 141 related publications. The selection of publications that are potential and relevant to our topic is done by reading the title and abstract of the publication and obtained 46 titles of publications from the process. These publication articles are then read in depth and are classified based on the instrument innovations developed. 11 out of 46 publication documents are descriptive.

\section{RESUltS AND DISCUSSION}

Quantification of analytic concentration using spectrophotometry through Beer Law analysis is an important aspect of the chemistry curriculum. Given the limited resources in many high and tertiary schools, it is not surprising that some authors have developed how to make a simple, portable, and inexpensive spectrophotometer and colorimetric [23].

\section{A. Instrument Developed}

Based on the analysis conducted on 46 publications, we classify them according to the types of developed instruments. The development aims to make instrument spectrometry more environmentally friendly, simple and easy to make and use. The classification of the instrument developed and introduced
TABLE I. THE LIST OF ARTICLE REPORTING THE DEVELOPMENT OF SPECTROPHOTOMETERS INSTRUMENT

\begin{tabular}{|l|l|l|l|}
\hline No & \multicolumn{1}{|c|}{$\begin{array}{c}\text { Instrument } \\
\text { Type }\end{array}$} & $\begin{array}{c}\text { Number of } \\
\text { publications }\end{array}$ & References number \\
\hline 1 & UV-Vis & 15 & {$[2,8,11,13,15,23-32]$} \\
\hline 2 & Flame (AAS) & 3 & {$[18],[33],[19]$} \\
\hline 3 & HPLC & 1 & {$[34]$} \\
\hline 4 & FTIR & 1 & {$[35]$} \\
\hline 5 & Colorimetric & 10 & {$[9,12,14,36-42]$} \\
\hline 6 & MS & 1 & {$[43]$} \\
\hline 7 & NMR & 2 & {$[44],[45]$} \\
\hline 8 & Others & 13 & {$[3,10,20,46-55]$} \\
\hline
\end{tabular}

Table 1 shows the distribution of instruments developed from journal articles reviewed. Other instruments developed in the table above include Raman Spectrometry, Florometry, development of parts of the spectrophotometer, and development of simulation instrument spectrometry using Virtual Reality and Augmented Reality

\section{B. Specific Technology Used}

The development of spectrophotometer is carried out covering 2 important parts of the instrument, namely the light source, and the detector. However, some articles do not express this clearly. Following are the results of article classification based on light source technology and detectors used:

TABLE II. The TECHNOLOGY USED to MAKE INSTRUMENTS

\begin{tabular}{|c|c|c|c|c|}
\hline No & $\begin{array}{c}\text { Part of } \\
\text { instrument }\end{array}$ & $\begin{array}{c}\text { The technology } \\
\text { used }\end{array}$ & $\begin{array}{l}\text { Number of } \\
\text { publications }\end{array}$ & $\begin{array}{c}\text { References } \\
\text { number }\end{array}$ \\
\hline \multirow{4}{*}{1} & \multirow{4}{*}{$\begin{array}{l}\text { Light } \\
\text { Source }\end{array}$} & LED & 12 & $\begin{array}{l}{[2,3,9-} \\
11,14,15,24,2 \\
8,39,51,53]\end{array}$ \\
\hline & & Laser pointer & 1 & {$[56]$} \\
\hline & & Digital Camera & 1 & [13] \\
\hline & & Flame & 3 & {$[18,19,33]$} \\
\hline \multirow{6}{*}{2} & \multirow{6}{*}{ Detector } & $\begin{array}{l}\text { Smartphone } \\
\text { camera }\end{array}$ & 10 & $\begin{array}{l}{[12,15,19,23,3} \\
2,36-38,40,41]\end{array}$ \\
\hline & & Arduino & 2 & {$[11],[52]$} \\
\hline & & Photodiode & 3 & $\begin{array}{ll}{[31],} & {[18],} \\
{[11]} & \\
\end{array}$ \\
\hline & & Digital Camera & 3 & $\begin{array}{ll}{[30],} & {[13],} \\
{[12]} & \\
\end{array}$ \\
\hline & & LED & 5 & {$[2,3,9,24,28]$} \\
\hline & & Lux Meter & 1 & {$[56]$} \\
\hline 3 & All & $\begin{array}{l}\text { Computer } \\
\text { Simulation }\end{array}$ & 5 & {$[20,42-44,48]$} \\
\hline
\end{tabular}

Table 2 describe the various technologies used to develop spectrophotometers instruments, besides that construction of instrument developed also has various variations, such as the use of 3D plastic printing [15,54,57], Lego [2,9], shoe boxes [32], and wood [30]. LEDs are the most preferred alternative light source by researchers. This is because LEDs are easy to obtain and have low prices.

The transformation of education in the 21 st century provides a new paradigm for the way teachers teach to 
TABLE IV. FOCUS OF RESEARCH SUBJECTS

facilitate students to be able to acquire the skills needed [58] The teacher must be able to connect technology advances with learning in the classroom. The use and development of technology such as smartphones detector in the world of chemical education make it very easy for students to read experimental data [59].

Other studies report the use of smartphone cameras in the spectrophotometry analysis. This method eliminates the need for photodetectors but remains relatively complicated. The report also appears in research that illustrates how smartphones can be used to do colourimetric and fluorescence analysis. This experiment further simplifies the process that allows the Beer's Law experiment to be conducted in almost all high school laboratories. However, this experiment requires rather sophisticated digital photo analysis. Besides, this experiment does not allow students to explore the process of absorption of light with samples that occur in spectrophotometry instruments. [23].

The experiments presented by Kuntzleman allow students to analyze Beer's Law with a smartphone camera [23]. The settings are very simple; data collection is fast and easy. Besides, the process of conducting experiments enables students to quantitatively and qualitatively explore the concepts and equations involved in the absorption of spectrometry [23].

In addition to the smartphone camera application as a detector, other research also utilizes photos and videos from smartphone cameras in science learning [60]. The results show that using photos and videos taken on mobile phones supports teachers to bring the outside world to the classroom and also makes it easy to give instructions, assess student learning and correct student misconceptions. Another advantage of using smartphones is that it enables the capture of previously unseen phenomena by encouraging closer observation than usual [60].

\section{Pedagogical Approaches Used}

In addition to looking at the technology used, the focus of the review is to look at the pedagogical aspects used. Pedagogical aspects data are shown in Table 3 and 4.

TABLE III. The PedAgOgICAL APPROACH USED

\begin{tabular}{|c|c|c|c|}
\hline No & Pedagogical Approaches & $\begin{array}{l}\text { Number of } \\
\text { publications }\end{array}$ & $\begin{array}{l}\text { References } \\
\text { number }\end{array}$ \\
\hline 1 & Project Based Learning & 4 & {$[8,11,26,32,38]$} \\
\hline 2 & Problem-Based Learning & 2 & [49], [47] \\
\hline 3 & Game Activity & 1 & [46] \\
\hline 4 & $\begin{array}{l}\text { Multimedia } \quad \text { Based } \\
\text { Learning }\end{array}$ & 1 & [42] \\
\hline 5 & Computer Based Learning & 1 & [52] \\
\hline 6 & Systematic Approach & 1 & [48] \\
\hline 7 & $\begin{array}{l}\text { Guided-Inquiry } \\
\text { Experiment }\end{array}$ & 1 & [24] \\
\hline 8 & Experiments & 22 & $\begin{array}{l}{[2,3,9,10,12-} \\
15,18- \\
20,23,25,27- \\
30,34,35,40,41,55]\end{array}$ \\
\hline 9 & Class Demonstration & 2 & {$[33],[53]$} \\
\hline 10 & Workshop & 1 & [45] \\
\hline
\end{tabular}

\begin{tabular}{|l|l|l|l|}
\hline No & \multicolumn{1}{|c|}{$\begin{array}{c}\text { Research } \\
\text { Subject }\end{array}$} & $\begin{array}{c}\text { Number of } \\
\text { publications }\end{array}$ & \multicolumn{1}{c|}{ Articles } \\
\hline 1 & $\begin{array}{l}\text { Undergraduate } \\
\text { Student }\end{array}$ & 18 & $\begin{array}{l}{[11,19,20,24,26,27,30,35,4} \\
2,43,46,47,49,52,53,55,56, \\
61]\end{array}$ \\
\hline 2 & $\begin{array}{l}\text { Senior High } \\
\text { School }\end{array}$ & 7 & {$[10,12,13,18,25,29,45]$} \\
\hline 3 & Both & 18 & $\begin{array}{l}{[2,3,9,14,15,23,28,31-} \\
34,36-41,44]\end{array}$ \\
\hline
\end{tabular}

Based on table 3, it is known that the pedagogical approach used by researchers to develop spectrophotometer instruments is quite varied. The experimental method becomes the most commonly used method. Besides, the project-based learning method has also been used to improve various student skills. One that has been done is the use of project-based methods on spectrophotometer experiments to improve students' creative thinking skills [8]. This method allows students to build their version of a simple spectrophotometer.

There are five important features of applying project-based learning in student-made simple spectrophotometer experiments; authentic questions or problems that drive activities and organize concepts and principles; community of enquiry between students, teachers, and community members; the use of cognitive tools; student involvement in investigations; and a series of products which answer problems [8].

Table 4 shows the development and use of this simple spectrophotometer has been successfully conducted at various levels of education. This proves that at the high school level they are able to receive spectrophotometer lessons and experiments. This has become one of the advantages of developing a simple, portable and inexpensive spectrophotometer so that it can be developed independently by teachers and students in high school. Even one of the studies conducted by Lafratta shows that spectrophotometer instruments can be taught to junior high school students [18].

Further analysis resulted in minimal student participation in the process of developing a simple spectrophotometer. Most researchers develop their simple spectrophotometer for later use by students. Several studies have shown that involving students in the process of developing a simple spectrophotometer will improve their various skills. This makes further research opportunities to develop a simple spectrophotometer by involving more student activities in the process.

\section{CONCLUSION}

Innovations for developing spectrometry instruments that are simple, portable and inexpensive have been conducted for various types of instruments. The UV-Vis instrument is the most developed. This opens up opportunities for other researchers to develop other types of spectrophotometer instruments, with innovations different from those reported. The use of LED technology as a light source and a smartphone camera as a detector is an innovation that is currently 
developing. In addition, the augmented reality application to introduce laboratory spectrometry instruments is a unique innovation. The development and the use of simple spectrophotometer have been successfully conducted at various levels of education including high school. This proves that simple, portable and inexpensive spectrophotometers can be used and developed at the high school level. Many ways can be used to develop spectrophotometer instruments in the classroom, such as using a project-based learning approach, problem-based learning, guided-inquiry and experiment. Besides, it was concluded that not many researchers involved the students to design and develop their spectrophotometers.

\section{REFERENCES}

[1] A. Lema, E.M. Aljinovic and M.E. Lozano, "Using a Homemade Spectrophotometer in Teaching Biosciences," Biochem Mol Biol Educ vol. 30, pp. 106-10, 2002.

[2] E.V. Kvittingen, L. Kvittingen, B.J. Sjursnes and R. Verley, "Simple and Inexpensive UV-Photometer Using LEDs as Both Light Source and Detector," J Chem Educ, vol. 93, pp. 1814-7, 2016.

[3] E.V. Kvittingen, L. Kvittingen, T.B. Melø, B.J. Sjursnes and R. Verley, "Demonstrating basic properties of spectroscopy using a self-constructed combined fluorimeter and UV-Photometer," J Chem Educ, vol. 94, pp. 1486-91, 2017.

[4] W. Xiao, M. Xiao, Q. Fu, S. Yu, H. Shen and H. Bian H, et al., "A portable smart-phone readout device for the detection of mercury contamination based on an aptamer-assay nanosensor," Sensors (Switzerland), vol. 16, 2016.

[5] W. Erhardt, "Instrumental Analysis in the High School Classroom : UV - Vis Spectroscopy,” J Chem Educ,vol. 84, pp. 1024-6, 2017.

[6] A.B.D. Nandiyanto, R. Ragadhita, A.G. Abdullah, F. Triawan, G.K. Sunnardianto and M, Aziz, "Techno-Economic Feasibility Study of Low-Cost and Portable Home-Made Spectrophotometer for Analyzing Solution Concentration,” J Eng Sci Technol, vol. 14, pp. 599-609, 2019.

[7] A.B.D. Nandiyanto, R. Zaen, R. Oktiani, A.G. Abdullah and L.S. Riza, "A Simple, Rapid Analysis, Portable, Low-cost, and Arduino-based Spectrophotometer with White LED as a Light Source for Analyzing Solution Concentration,” Telkomnika, vol. 16, pp. 580-5, 2018.

[8] C. Diawati, Liliasari, A. Setiabudi and Buchari, "Using Project-Based Learning to Design, Build, and Test Student-Made Photometer by Measuring the Unknown Concentration of Colored Substances," J Chem Educ, vol. 95, pp. 468-75, 2018.

[9] J. Asheim, E.V. Kvittingen, L. Kvittingen and R. Verley, “A simple, small-scale lego colorimeter with a light-emitting diode (LED) used as detector. J Chem Educ, vol. 91, pp. 1037-9, 2014.

[10] B.T. Wigton, B.S. Chohan, C. McDonald, M. Johnson, D. Schunk, R. Kreuter, "A portable, low-cost, LED fluorimeter for middle school, high school, and undergraduate chemistry labs," J Chem Educ, vol. 88, pp. 1182-7, 2011.

[11] R.L. McClain, "Construction of a photometer as an instructional tool for electronics and instrumentation," J Chem Educ, vol. 91, pp. 747-50, 2014.

[12] E. Kehoe an R.L. Penn, "Introducing colorimetric analysis with camera phones and digital cameras: An activity for high school or general chemistry," J Chem Educ, vol. 90, pp. 1191-5, 2013.

[13] J.M. Quagliano and C.A. Marks, "Demystifying spectroscopy with secondary students: Designing and using a custom-built spectrometer," J Chem Educ, vol. 90, pp. 1409-10, 2013.

[14] C.M. Clippard, W. Hughes, B.S. Chohan and D.G. Sykes, "Construction and characterization of a compact, portable, low-cost colorimeter for the chemistry lab," J Chem Educ., vol. 93, pp. 1241-8, 2016.
[15] E.K. Grasse, M.H. Torcasio, A.W. Smith A.W and U.V. Teaching, "Vis Spectroscopy with a 3D-Printable Smartphone Spectrophotometer," J Chem Educ, vol. 93, pp. 146-51, 2016.

[16] P.A. Iyere, "The Development of Innovative Laboratory Experiments with UV-Visible Spectrophotometer," J Chem. Educ. Vol. 77, pp. 153, 2009.

[17] F. Wakabayashi, K. Hamada, "Cost-Effective Teacher A DVD Spectroscope : A Simple , High-Resolution Classroom Spectroscope,” J. Chem. Educ., vol. 83, pp. 56-8, 2006.

[18] C.N. Lafratta, S. Jain, I. Pelse, O. Simoska and K. Elvy, "Using a Homemade Flame Photometer To Measure Sodium Concentration in a Sports Drink," J. Chem. Educ., vol. 90, pp. 372-5.

[19] E.P. Moraes, N.S.A. Da Silva, C.D.L.M. De Morais, Das Neves LS, K.M.G. De Lima, "Low-cost method for quantifying sodium in coconut water and seawater for the undergraduate analytical chemistry laboratory: Flame test, a mobile phone camera, and image processing," J. Chem. Educ., vol. 91, pp. 1958-60, 2013.

[20] J.A. Naese, D. McAteer, K.D. Hughes, C. Kelbon, A. Mugweru, and J.P. Grinias, "Use of Augmented Reality in the Instruction of Analytical Instrumentation Design,” J. Chem. Educ., vol. 96, pp. 593-6, 2019.

[21] N. Papadopoulos, M. Limniou, G. Koklamanis, A. Tsarouxas, M. Roilidis and S.W. Bigger, "Spec UV-Vis: An Ultraviolet-Visible Spectrophotometer Simulation," J. Chem. Educ., vol. 78, pp, 1560, 2009.

[22] N.S. Evans, R.B. Stevenson, M. Lasen, J.A. Ferreira JA, Davis J. Approaches to embedding sustainability in teacher education: A synthesis of the literature. Teach Teach Educ 2017;63:405-17. doi:10.1016/j.tate.2017.01.013.

[23] T.S. Kuntzleman and E.C. Jacobson, “Teaching Beer's Law and absorption spectrophotometry with a smart phone: A substantially simplified protocol,” J. Chem. Educ. vol. 93, pp. 1249-52, 2016.

[24] J.J. Wang, R.J.R. Núñez, E.J. Maxwell and W.R. Algar, "Build Your Own Photometer: A Guided-Inquiry Experiment To Introduce Analytical Instrumentation," J. Chem. Educ. vol. 93, pp. 166-71, 2016.

[25] J.M. Carraher, S.M. Curry and T.P. Tessonnier, "Kinetics, Reaction Orders, Rate Laws, and Their Relation to Mechanisms: A Hands-On Introduction for High School Students Using Portable Spectrophotometry," J. Chem. Educ. vol. 93, pp, 172-4, 2016.

[26] W.V. Wilson, E. Wilson, "Authentic performance in the instrumental analysis laboratory: Building a visible spectrophotometer prototype," J. Chem. Educ. vol. 94, pp. 44-51, 2016.

[27] A.L. Adams-McNichol, R.C. Shiell and D.A. Ellis, "Accurate, Photoresistor-Based, Student-Built Photometer and Its Application to the Forensic Analysis of Dyes," J. Chem. Educ. 2019.

[28] B.J. Place, "Activity Analysis of Iron in Water Using a Simple LED Spectrophotometer," J. Chem. Educ. vol. 96, pp. 714-9.

[29] K. Dooling, K. Bodenstedt and M.F.Z. Page, "A caffeinated boost on UV spectrophotometry: A lab for high school chemistry or an introductory university chemistry course," J. Chem. Educ. vol. 90, pp. 914-7, 2013.

[30] J.R. Vanderveen, B. Martin, K.J. Ooms, "Developing Tools for Undergraduate Spectroscopy: An Inexpensive Visible Light Spectrometer," J. Chem. Educ. vol 90, pp. 894-9, 2013.

[31] D.R. Albert, M.A. Todt and H.F. Davis, "A Low-Cost Quantitative Absorption Spectrophotometer," J. Chem. Educ. vol. 89, pp. 1432-5, 2012.

[32] B.S. Hosker, "Demonstrating Principles of Spectrophotometry by Constructing a Simple, Low-Cost, Functional Spectrophotometer Utilizing the Light Sensor on a Smartphone," J. Chem. Educ. vol. 95, pp. 178-81, 2018.

[33] B. Néel, A.G. Crespo, D. Perret, T. Cherubini and E. Bakker, "Camping Burner-Based Flame Emission Spectrometer for Classroom Demonstrations," J. Chem. Educ. vol. 91, pp. 1655-60, 2014.

[34] B. Stankus, R. White and B. Abrams, "Effective and Inexpensive HPLC Analogue for First-Year Students: Buret Chromatography of Food Dyes in Drinks," J. Chem. Educ., vol. 96, pp. 739-44, 2019. 
[49] S.E. Nielsen, J.P. Sca and E.J. Yezierski, "Detecting Art Forgeries: A Problem-Based Raman Spectroscopy Lab,” J. Chem. Educ. vol. 91, pp. 446-50, 2014

[50] E. Maslowsky, "Comparison of the Electromagnetic Spectra of Common Light Sources: A General Chemistry Laboratory Exercise," J Chem Educ., vol. 90, pp. 1488-92, 2013.

[51] B.T. Wigton, B.S. Chohan, R. Kreuter and D. Sykes, "The Characterization of an Easy-to-Operate Inexpensive Student-Built Flourimeter," J. Chem. Educ., vol. 88, pp. 1188-93, 2011.

[52] J.P. Grinias, J.T. Whitfield, E.D. Guetschow, R.T. Kennedy, "An inexpensive, open-source USB Arduino data acquisition device for chemical instrumentation,” J. Chem. Educ., vol. 93, pp. 1316-9, 2016.

[53] W.R. Algar, C.A.G. De Jong, E.J. Maxwell and C.G. Atkins, "Demonstration of the Spectrophotometric Complementary Color Wheel Using LEDs and Indicator Dyes," J. Chem. Educ., vol. 93, pp. 162-5, 2016.

[54] E.J. Davis, M. Jones, D.A. Thiel and S. Pauls, "Using Open-Source, 3D Printable Optical Hardware to Enhance Student Learning in the Instrumental Analysis Laboratory," J. Chem. Educ., vol. 95, pp. 672-7, 2018.

[55] A. Nori De Macedo, S. Mathiaparanam, R. Ly, and P. Britz-Mckibbin, "Surveying Iodine Nutrition Using Kinetic Spectrophotometry: An Integrative Laboratory Experiment in Analytical Chemistry for Population Health,” J. Chem. Educ., vol. 95, pp. 1029-34, 2018.

[56] C. Diawati, A. Setiabudi, "Students ' Construction of a Simple Steam Distillation Apparatusand Developmentof Creative Thinking Skills: A Project-Based Learning," AIP Conf. Proc., 2017.

[57] L.A. Porter, "3D Printable Resources for Engaging STEM Students in Laboratory Learning Activities and Outreach Programs: Inexpensive and User-Friendly Instrument Kits for Educators," Mater Res. Soc. Pp. 2937-42, 2018

[58] A.S. Shidiq and S. Yamtinah, "Pre-service chemistry teachers' attitudes and attributes toward the twenty-first century skills," J. Phys. Conf. Ser., vol. 1157, pp. 1-8, 2019.

[59] S.M. Al-Balushi, A.S. Al-Musawi, A.K. Ambusaidi and F.H. Al-Hajri, "The Effectiveness of Interacting with Scientific Animations in Chemistry Using Mobile Devices on Grade 12 Students' Spatial Ability and Scientific Reasoning Skills," J. Sci. Educ. Technol., vol. 26, pp. 7081, 2017.

[60] S.Y. Ekanayake and J. Wishart, "Mobile phone images and video in science teaching and learning," Learn Media Technol., vol. 39, pp. 22949, 2014.

[61] E.J. Davis, S. Pauls and J. Dick, "Project-Based Learning in Undergraduate Environmental Chemistry Laboratory: Using EPA Methods To Guide Student Method Development for Pesticide Quantitation,”J. Chem. Educ., 2016. 